\title{
Ten Years After the Asian Financial Crisis: The Fragility and Strength of China's Financial System
}

\section{Yu Yongding*}

\author{
1 Introduction \\ Ten years have passed since the Asian financial crisis. \\ With the benefit of hindsight, we are now in a much \\ better position to grasp the nature of the crisis and \\ digest the lessons that we thought we had learnt \\ during the years since the crisis.
}

There is no doubt whatsoever that, over the past ten years since the crisis, the Chinese economy has been performing extremely well. In 2006, China's growth rate of GDP was 10.7 per cent, with an inflation rate around 2 per cent (though in the last quarter of 2006, the inflation rate showed some acceleration). In 2006, China's current account and capital account surpluses were US\$170 billion and US $\$ 60$ billion, respectively. The growth rate of net exports was more than 70 per cent, after having registered a growth rate of 220 per cent in 2005 . Although the Chinese Renminbi (RMB) exchange rate has appreciated by about 6 per cent against the US dollar since July 2005, the appreciation pressure on the RMB is unabated. To maintain the stability of the $\mathrm{RMB}$, the Chinese monetary authorities have intervened in the foreign exchange market constantly. China has run twin surpluses - current account surplus and capital account surplus - for more than one and a half decades. As a result, China's foreign exchange reserves have surpassed US $\$ 1$ trillion and are expected to increase continuously at a rate of US\$200 billion a year.

However, in recent years many observers of the Chinese economy have had a feeling of déjà vu and discussions about how far China is away from a crisis have re-emerged. The aim of this article is to identify the key threats to China's economic stability in the near future and discuss how China can prevent a crisis from happening in the face of these threats. In Section 2, the main lessons for China of the Asian financial crisis are highlighted. In Section 3, drawing on the experience of the Asian financial crisis, the main points of vulnerability of China's financial system, the banking system in particular, are identified and their reforms examined. Section 4 is about the dilemma China's monetary authorities have been facing since China's reform of its exchange rate regime on 21 July 2005. Section 5 is about the role of capital controls in China's crisis prevention. The last section contains concluding remarks.

\section{The lessons China has learnt from the Asian financial crisis}

The experience of the Asian financial crisis has been studied carefully in China. There are three major lessons to which China has paid particular attention.

\subsection{Lesson 1: A healthy financial system is the key} for sustainable growth

All crisis-hard-hit countries had a fragile financial system characterised by high non-performing loan ratio and low capital adequacy. The crisis-affected countries' experience shows that high nonperforming ratio resulting from reckless lending in boom time will lead to bankruptcy of financial institutions when the economy is in a downturn. The insolvency of one or two major financial institutions caused by non-performing loans can lead to the breakdown of a whole array of financial institutions and bring the economy into a deep recession as happened in Thailand and some other East Asian countries during the Asian financial crisis. The credit crunch caused by non-performing loans can also lead to a long-drawn deflation similar to that seen in Japan in the 1990s. 
With a healthy well-regulated financial system, reckless credit expansion tends not to happen in the first place. When an economy slows down due to internal and/or external shocks or cyclical factors, with a healthy financial system, bank run and capital flight normally will not happen. When a currency is under attack, for whatever reason, with a healthy financial system, the monetary authorities will be able to raise the interest rate as high as necessary to defend its currency. In contrast, with a fragile financial system, interest rate hikes will lead to massive bankruptcy of financial institutions and enterprises. Therefore, the restructuring of the financial system, especially the banking system, has become the foremost important task of China's economic reform since the second half of the 1990s.

\subsection{Lesson 2: The exchange rate should be flexible as well as stable}

Experience shows that a stable and competitive exchange rate is essential for an export-oriented developing country. However, an inflexible exchange rate will risk a balance of payments crisis and a currency crisis when it is overvalued, or create economic bubbles and inflation when it is undervalued. A flexible exchange rate would make currency misalignment smaller and trade account more balanced. A timely relief of appreciation or devaluation pressure by exchange rate adjustment would contain excessive capital movement and make a big correction less necessary. In contrast, an inflexible exchange rate postpones a necessary adjustment, accumulates misalignment and eventually results in drastic correction with devastating consequences for the economy. For most Asian countries, because of the liberalisation of capital account, a flexible exchange rate will allow them to maintain the independence of monetary policy.

\subsection{Lesson 3: The liberalisation of capital control should be implemented in a steady and orderly fashion}

The liberalisation of capital controls will make the cross-border allocation of resources more efficient by eliminating the rent-seeking opportunity and reducing the social cost of the evasion of the capital control. However, Asian countries' experience shows that due to the fragility of the financial system and weak corporate governance, large fluctuations of the exchange rate caused by free movement of capital flows can be too disruptive for the economy in general and for the trade sector in particular. On the one hand, developing countries need independent monetary policy, due to a lack of synchronisation of economic cycles with major developed countries. On the other hand, they need to maintain a significant degree of exchange rate stability, because of the structural rigidity of their economies. To strike a balance, they must maintain a certain degree of control over capital flows (Williamson 1995).

For developing countries, capital flows are inherently destabilising, because their financial markets are too shallow. Free movements of capital more often than not exacerbate economic instability (Rodrick 1998). Before the Asian financial crisis, due to the large interest rate differences between Thai assets and foreign assets, Thai financial institutions borrowed heavily from abroad, from Japan in particular, and then lent the money to domestic borrowers. The 'carry trade' enabled financial institutions to earn huge profits. The reckless lending by financial institutions created estate and equity bubbles. When the bubbles burst, many financial institutions became either illiquid or insolvent. Some financial institutions went bankrupt. The fall of major financial institutions led to panic and a run on banks. Capital flows reversed suddenly. The capital flight led to the currency crisis. According to Thai economists, the Thai financial crisis can be best characterised as a 'capital account crisis'. The sudden reversal of capital flows was the single most important culprit of the crisis. Capital inflows can increase dramatically out of irrational exuberance, and capital outflow can also increase dramatically out of irrational panic (Radelet and Sachs 1998; Woo et al. 2000). The question of what triggered the Asian crisis is not important triggers can present themselves at any time. The key is how to manage capital flows in an effective fashion. Ideally, whatever happens, developing countries should be able to manage the movement of capital in such a way that capital flows cannot reverse suddenly. The opening of the financial service sector should not be allowed to lead to automatically opening the capital account.

There are many other important lessons that we have learned. For example, the lack of regional financial cooperation was one important reason for the failure of the Asian countries. 
Table 1 Balance sheet of AMCs

\begin{tabular}{ll}
\hline Assets & Liabilities \\
\hline 1,400 billion yuan NPLs & 570 billion yuan PBOC re-lending \\
-405 billion yuan NPLs & 820 billion yuan financial bonds \\
+405 billion equities & \\
-866 billion yuan NPLs & \\
+181 billion yuan cash & \\
\hline
\end{tabular}

40 billion yuan injection by the ministry of finance

Source Nafang Zhoumo (2006) Southern Weekend 28 September: C22. PBOC, The People's Bank of China.

\section{China's financial fragilities and China's reform of the banking system}

China's banks, like in all crises-hit East Asian countries, once were beset by high non-performing loan ratios, low capital adequacy and poor corporate governance. As pointed out by Lardy, 'the most serious threat to macroeconomic stability in China is the possibility of a domestic banking crisis... The central precondition for a crisis, a largely insolvent banking system, already exists'. ${ }^{1}$ Because of the similarity between China and the crisis-hit East Asian countries in terms of financial fragility, many scholars and economic journals repeatedly predicted that the Chinese economy would fall. Although these predictions have failed to materialise so far, there is no reason for China to be complacent. No-one can rule out the possibility that a financial crisis of some kind may occur in China in the foreseeable future.

\subsection{High non-performing loan (NPL) ratio}

In 1998, China's true non-performing loan ratio was perhaps higher than those reported in Thailand and Korea prior to the onset of the Asian financial crisis in 1997. The lesson of the 1980s is that financial distress is likely to become systemic when nonperforming loans, net of provisions, reach 15 per cent of total loans. In the late 1990s, China officially admitted that the highest NPL/loan ratio was about 25 per cent. After the Asian financial crisis, the high $N P L$ ratio was identified as the most vulnerable point of the Chinese economy. Efforts were taken to deal with this problem head on. From 1995 to 1998, a large amount of debts had been re-scheduled and 190 billion yuan in bad loans had been struck off the book. To write-off bad loans, the banks must provide corresponding loan loss provision. According to the international standard, the loan loss provision should be 1.25 per cent of total bank loans. In China, before 1987, there was no requirement for loan loss provision. Since 1992 the ratio was 0.5 per cent, and on top of it, 0.1 per cent was requested to be added each year, until the ratio increased to 1 per cent.

To speed up the process of reducing the NPL ratio, in 1999, four asset management companies (AMCs) were established to securitise banks' non-performing loans. For the operation of the AMCs the following procedures were adopted: (a) AMCs buy commercial banks' NPLs at face-value (1:1); (b) banks increase their holding of cash injected by AMCs and reduce the same amount of assets (NPLs); (c) AMCs achieve the controlling shares of the enterprises that had borrowed from the banks and failed to repay their debts. AMCs will restructure the enterprises so as to make them profitable in four years; (d) AMCs' holding would last only four years. In the end, they must sell their share on the market. They had to try to achieve a recovery ratio as high as possible (30 per cent would be fine); (e) eventually, AMCs' losses would be footed by the ministry of finance.

The funds of AMCs were mainly obtained from the following sources: (1) The Ministry of Finance (initial capital and follow-up capital); (2) Sales of Special Bonds guaranteed by the Ministry of Finance;

(3) Borrowing from banks. Table 1 summarises the process of writing off non-performing loans by AMCs in China since the late 1990s until recently. 
From Table 1, it can be seen that the AMCs helped banks to eliminate 1,400 billion yuan NPLs off their books. Among them, 405 billion yuan NPLs were swapped for equities of the enterprises that owned the debts, and 866 billion yuan bad loans were sold to domestic and international investors.

According to the design, the AMCs life expectancy is ten years. ${ }^{2}$ Before the end of their lifetime, AMCs should sell their holding of bad loans at a discount. The potential buyers of $\mathrm{AMC}$ assets are:

(1) enterprises that participated in the debt-equity swap programme, if they become profitable later (2) holding companies of the enterprises whose debt have been taken over by AMCs; (3) local governments and other enterprises in the locality; (4) stock market, if the companies will be able to be listed on the market after restructuring and their shares are salable; (5) foreign buyers.

China's debt-equity swap programme is still in progress. Owing to the moral hazard involved, many economists are sceptical about the programme. It seems that lack of effective capital markets in which the value of bad debts and collateral can be measured objectively is the key obstacle for the smooth implementation of the programme. By the end of April 2006, among the disposed NPLs of 866.34 billion yuan by the four asset management companies, 180.56 billion yuan was recovered. The cash recovery rate is 24.2 per cent. ${ }^{3}$

The cost of cleaning up the banking system is extremely high. In fact, according to an official from The People's Bank of China (PBOC), 5 trillion yuan were spent. ${ }^{4}$ In the future, having cleaned up their books with the help of the Ministry of Finance, the four asset management companies will perhaps be re-shaped into investment banks into which strategic investors will be invited. ${ }^{5}$

Owing to the writing off of NPLs as well as the rapid expansion of bank loans over the past several years, Chinese Banks' NPL ratio has fallen to a comfortable level. By the end of the first-quarter of 2005, the total amount of NPLs of China's commercial banks was 1,800 billion yuan, and the NPL ratio fell to 12.4 per cent.

\subsection{Low capital adequacy}

Low capital adequacy was another important point of vulnerability in China's banking system. In 1998, in

\section{Table 2 The preparation for the injection}

Assets Liabilities

Reserves (-270)

Govt. bonds (+270)

\section{Capital}

order to raise the capital adequacy of the four banks from 3.5 per cent to 8 per cent, 270 billion RMB was injected by the PBOC. The steps taken by the PBOC went as follows.

First, the PBOC lowered the reserve requirement from 13 per cent to 8 per cent, and scrapped the excess reserve requirement. As a result, 270 billion $\mathrm{RMB}$ reserve assets were released from the balance sheet of the PBOC. Second, the four banks used the 270 billion RMB to buy the special bonds issued by the government (Table 2).

Third, the government injected the 270 billion RMB into the four banks as capital. The end result of this operation is that on the asset side of the balance sheet of the four banks, there is an increase in government bond holding of 270 billion RMB, and on the liability side of the balance sheet of the four banks, there is a corresponding increase in capital in exchange for equity rights (Table 3 ).

There are some important features of the government bonds:

- The maturity of the government special bonds is 30 years. The government should have no problem in redeeming the bonds.

- The special bonds can be traded in the inter-bank bond market. The liquidity of the special bonds is good.

- The interest rate of the bonds is 7.2 per cent which means that the government has to pay interest of 19.4 billion yuan. The government can expect to be compensated by collecting more tax on bank profits, if the banks have improved their profitability, owing to the re-capitalisation.

As a result of the re-capitalisation, the four major banks' capital adequacy reached 8 per cent. It was ascertained at the time that in the next 4-7 years, the adequacy of the four could be maintained at that 
Table 3 Final shape of the balance sheet

Assets Liabilities

Cash injection (+270)

Reserves (-270)

Govt. bonds (+270)

\begin{tabular}{ll}
\hline Capital \\
\hline Government share $(+270)$
\end{tabular}

level. The optimism of the assertion was proved wrong just a few years later. After this and another bailout action later, further loan losses quickly eroded the banks' capital bases. Consequently, more bailouts were carried out in $2004{ }^{6}$

In 2004, the Chinese government decided to inject public money into China's troubled commercial banks again. This time, US $\$ 45$ billion out of China's huge foreign exchange reserves were injected into two big state-owned banks, Bank of Construction of China and Bank of China. The Chinese authorities have been frustrated by the lack of progress in the banking reform. The need for re-capitalisation only four years after the first injection of 270 billion yuan is a clear demonstration of the failure of the old approach. The new thinking behind the Chinese monetary authorities' decision is that the participation of international strategic investors is a necessary condition for the success of its bank reforms. The purpose of the re-capitalisation is aimed at making the books of the two banks up to international standards so that the IPO can be made and international strategic investors can be attracted as soon as possible. In 2006 another large capital injection of US\$15 billion was made for China's largest commercial bank, Industrial and Commercial Bank of China (ICBC).

Foreign exchange reserves are not net assets of the public sector, and they were invested by the central bank in the banks via a new state company called Central Huijin Investment Company which is owned by the PBOC. As a result of capital injection, Hujin Investment Company became the sole owner of the commercial banks (100 per cent shareholder of the two banks). In order to prevent any inflationary effect of the injection, the foreign exchange reserves received by the banks are not allowed to purchase
RMB for domestic spending. Later, the third bank, Industrial and Commercial Bank of China also received capital injection.

Because of the improvement in capital base and profitability, the three banks were listed in Hong Kong successfully. US\$42 billion capital was raised. 'International strategic investors' became important minority shareholders. Bank of China (BOC) raised US\$9.7 billion in its IPO, Construction Bank of China (CBC) US\$ 9.2 billion, and Industrial and Commercial Bank of China (ICBC) US\$21.9 billion (the largest ever $I P O$ in the world). The soaring share prices made ICBC the world's largest bank. So far China's three big commercial banks that have received the injection have been doing well. However, whether there is a fundamental improvement in corporate governance of these banks is still too early to tell. Indeed, after bad debt write-off, capital injection, public listing, installation of new IT equipment and other technical progression, China's commercial banks have come up to international standards. However, I am not sure whether those more fundamental problems within China's banking system, such as nepotism, incompetence, susceptibility to government intervention and low efficiency have been solved. The cost of the banking reform over the past ten years has been enormous. It is not very likely that China's fiscal position will allow China to do the same a second time in the future, if China's commercial banks fall into serious trouble again. The upside of the capital injection is to provide commercial banks with a fresh start. The downside of the capital injection is the worsening of moral hazard. Few people within the banks are punished because of their misbehaviour. Who cares about good behaviour, if every one believes that the government will pick up the pieces eventually? Maybe the new shareholders care, but to what extent the so-called strategic investors can play a role to improve the banks' corporate governance remains to be seen.

\subsection{Strengthening banking supervision}

Finally, a number of measures have been adopted aimed at strengthening banking supervision.

New decrees and regulations have been enacted to strengthen management and risk preventions. The increased efforts to conduct prudential supervision by the central bank achieved significant results. First, the segregation of commercial banking, trust and securities business generally has been completed. 
Figure 1 Growth rate of fixed assets investment vis-à-vis that of GDP

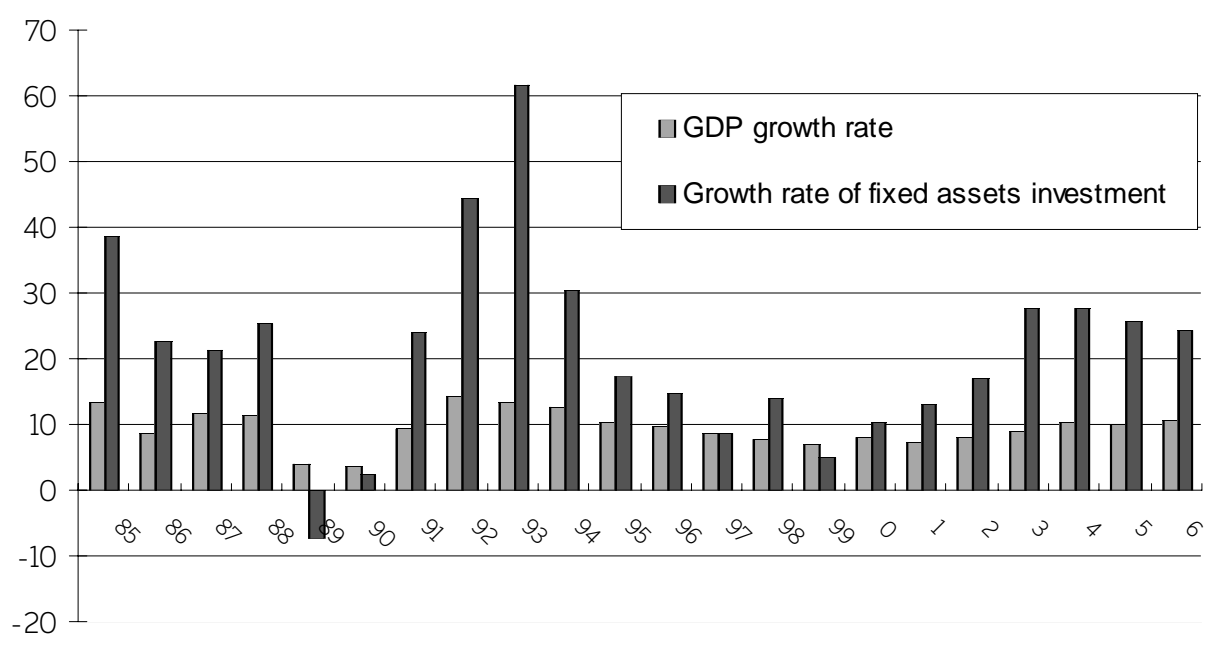

Note The GDP growth rate is in real terms. That of FAl does not remove price factor. However, since 1997, China's inflation rate has been very modest. Even taking the price factor into consideration, the growth rate of $\mathrm{FAl}$ is assumed higher that $20 \%$ per annum since 2003.

Sources China Statistical Yearbook, various issues, National Bureau of Statistics.

Second, the licensing of banking institutions and the fit and proper test for senior management have been further improved. Third, the central bank strengthened its ability to conduct analysis of supervisory information on commercial banks through off-site supervision as well as its capacity for early detection of risks. The commercial banks were informed on a quarterly basis of the results of offsite supervision. Fourth, the supervision of banks was also strengthened by strong enforcement actions. Fifth, some emerging financial risks were reduced. Last but not least, the China Banking Regulatory Commission (CBRC) was established to take overall charge of the supervision of China's banks. Since its establishment, banking supervision has been significantly strengthened.

\section{Trilemma facing China's monetary authorities} While the institutional reforms of China's financial system have been implemented over the past decade, as a response, to a large extent, to the Asian financial crisis, China has run into a new macroeconomic situation (Wang 2006). In contrast to East Asian countries before the crisis, which ran large current account deficits, China has run current account surpluses and capital account surpluses constantly since the early 1990s (Yongding 2005). In order to maintain the stability of the RMB exchange rate, the $\mathrm{PBOC}$ has intervened heavily in the foreign exchange market. The massive intervention means that the PBOC has injected huge amount of high powered money into the banking system. As a result, excessive liquidity has increased rapidly over the past three years.

Since late 2002, growth of the Chinese economy has accelerated. The growth rate of fixed assets investment has been very high; more than double of the growth rate of GDP (Figure 1). By the end of 2005, according to official sources, the investment rate was 48.6 per cent of GDP.? The government is worried about overcapacity in years to come. Given the initial conditions as of 2005, the investment rate could be approaching 100 per cent in less than a decade.

On top of the high growth rate of Fixed-Asset Investment (FAl), soaring housing prices is another important concern for the government (Table 4). The rapid rise of housing prices not only intensifies speculation in the real estate sector and hence leads to the creation of bubbles, but also causes the anger of the public. More recently, China's share prices are also soaring, which cannot be explained by the improvement in fundamentals. Indeed, the correction that happened in February 2007 could not be explained by deteriorating fundamentals either. 


\begin{tabular}{|c|c|c|c|c|c|c|}
\hline Year & $\begin{array}{l}\text { Average price } \\
\left(\text { yuan } / m^{2}\right)\end{array}$ & $\begin{array}{l}\text { Growth rate } \\
\text { of average } \\
\text { price (\%) }\end{array}$ & $\begin{array}{l}\text { Value of total } \\
\text { sale }\end{array}$ & $\begin{array}{l}\text { Growth rate } \\
\text { of value of } \\
\text { total sale (\%) }\end{array}$ & $\begin{array}{l}\text { Volume of } \\
\text { sale (unit: } \\
10,000 \mathrm{~m}^{2} \text { ) }\end{array}$ & $\begin{array}{l}\text { Growth rate } \\
\text { of volume of } \\
\text { sale (\%) }\end{array}$ \\
\hline 2003 & 6,438 & & 812 & & 1,262 & \\
\hline 2004 & 6,178 & -4 & 1,608 & 98 & 2,602 & 106 \\
\hline 2005 & 7,534 & 22 & 1,670 & 4 & 2,217 & -15 \\
\hline 2006 & 8,792 & 17 & 2,011 & 20 & 2,288 & 3 \\
\hline
\end{tabular}

Source Website of Beijing's Management of Housing and Real Estate Transactions. Reference News (19 January 2007).

In 2006, China's inflation was just 1.5 per cent. However, in December of 2006, the annualised growth rate of Consumer Price Index (CPI) rose to 2.8 per cent. Therefore, inflation is still on the radar screen of the PBOC.

To slow down the growth rate of FAl, contain real estate bubbles and maintain price stability, the PBOC has adopted a tight monetary policy. However, other things being equal, tight monetary policy means higher interest rates, which in turn means more capital inflows and higher pressure on RMB appreciation. It is obvious that China's aim of the maintenance of the stability of the RMB exchange rate is in direct contradiction with that of a tight monetary policy. To overcome this contradiction, in other words, to maintain both the stability of the $\mathrm{RMB}$ and the tightness of monetary policy at the same time, the $\mathrm{PBOC}$ has carried out a large-scale sterilisation operation to mop-up the excessive liquidity created by the central bank's intervention in the foreign exchange market.

Owing to the enormous scale of the sterilisation operation, in just three years, the PBOC sold out all the government bonds it had accumulated since 1998 when the government started to issue government bonds to stimulate a deflationary economy. The exhaustion of the bond holding by the $\mathrm{PBOC}$ means that there is no more room for the central bank to manipulate the asset side of its balance sheet. It turned to the liability side. In 2003 the PBOC began to issue central bank bills to mop up the excessive liquidity.

The key question is whether sterilisation can be carried out unlimitedly. Theoretically speaking, as long as the interest rates paid by the central bank on its bills is lower than the corresponding interest rates of American assets, e.g. the yields of treasury bills, the central bank should be able to carry on with sterilisation infinitively, and hence to maintain an effective control of the monetary base. However, the sale of central bank bills will push up the interest rates in money markets, which in turn will invite more capital inflows, and hence create the need for more sterilisation. This certainly is a not a sustainable process. Furthermore, to prevent the sterilisation from causing interest rates to rise, the PBOC sometimes issues the so-called designated central bank bills to commercial banks, which commercial banks have to buy with prices higher than the market prices. Because commercial banks have to buy increasingly large amounts of low yield central bank bills, their profitability will fall. Lower profitability will create a long-term negative impact on the fragile banking system.

On top of sterilisation by selling central bank bills, the $\mathrm{PBOC}$ has raised the reserve requirement rate seven times since 2003. By raising reserve requirements, a large amount of liquidity has been frozen. In fact, the increase in reserve requirements was the first important measure taken by the PBOC since the Chinese economy bottomed out from deflation that had started in 1997. In a typical market economy, the central bank will refrain from changing reserve requirements, because the measure is regarded as too drastic and clumsy. However, this seems not to be a problem for the Chinese economy. Though the rise of reserve requirements will cause some problems for commercial banks, the latter can adapt to the new situation by various measures. For commercial banks, the simplest way to 
respond to the tightening is to shift a proportion of excess reserves, which are kept for the purpose of settlement by commercial banks, into the account of mandatory reserves. However, the key issue here is that the increase in reserve requirement rate means increased tax on commercial banks, which certainly will impact negatively on commercial banks' performances

In summary, to achieve simultaneously the objectives of the maintenance of a stable exchange rate, a tight monetary policy and a good performance of the commercial banks is impossible. If the government wishes to achieve the three objectives at the same time, some compromise among these three objectives must be made. In fact, the PBOC has implemented a moderately tight monetary policy, and the excessive liquidity is not fully sterilised. At the same time, the RMB is allowed to re-value gradually so as to reduce the burden of the PBOC on sterilisation. Under these circumstances, all three objectives have been taken care of, but none of them have been achieved completely.

\section{China's financial stability and capital account liberalisation in the next five years}

Despite its extremely good economic performance in terms of growth rate and inflation, China has been confronted with increasingly serious structural problems. First, China's natural environment has been deteriorating. Second, its energy consumption has been soaring. Third, the gap of income distribution in China has been widening. Last but not least, China's current account imbalance has been worsening. Decision-makers have realised that China cannot carry on with its old investment and export-driven growth strategy, no matter how successful it was.

However, the adjustment of the growth strategy aimed at achieving a more balanced growth pattern cannot be completed in a short period of time. Personally, I think it at least will take five years. Because the twin surpluses and other imbalances will persist for quite a long time and the government has set to achieve the three contradictory objectives simultaneously, China's financial stability is likely to be compromised somewhat during the period of adjustment. Although it is entirely possible that China will muddle through again this time, it definitely will not be plain sailing. The Chinese government has to be extremely careful about excessive liquidity-led asset bubbles and/or inflation.
If China succeeds in maintaining the financial stability for another five years, the Chinese economy may eventually enter into a sustainable growth path.

The Chinese government does not wish to allow the $\mathrm{RMB}$ to appreciate rapidly and hence the process of appreciation of the RMB may last for many years five years at least, in my view. During this period of time, cross-border capital will continue to flow in to push up the RMB exchange rate and flood the economy with liquidity. Under this circumstance, the last line of defence left for the government in its effort to prevent a balance of payment crisis and currency crisis is to improve the management of capital flows so as to reduce speculative capital inflows and encourage orderly capital outflows, especially outflows in the form of outbound FDI.

Since 1979, foreign capital inflows in general and FDI in particular have played a key role in China's economic growth. Based on the lessons of the debt crisis of Latin American countries in the 1980s, China adopted a cautious attitude towards liberalisation of capital flows from the beginning. For many years, observers had criticised China for being too slow in liberalising the capital account. The Chinese government itself also felt embarrassed by the slowness. However, suddenly the shortcoming became a virtue when the Asian financial crisis broke out. Although China's financial system was as fragile as those crisis-affected countries in the region, if not worse, the Chinese currency (the RMB) escaped attacks by international speculators. In the wake of the Asian financial crisis, the pace of capital account liberalisation in China slowed down.

However, in recent years, capital account liberalisation again became a focus of policy debate. There are two main factors behind the recent changes. The first is China's commitment to open the financial services sector as a part of WTO deal signed in December 2001. The second are the tactics used by the Chinese monetary authorities for reducing appreciation pressure on the RMB. The tactics have taken the form of 'yanjin kuangchu' (strict control over capital inflows and loosening control over capital outflows) policy.

However, despite the new policy of yanjin kuanchu, capital inflows have continued to flow in rapidly through the current account as well as the capital account. The destinations of these capital inflows are 
China's money markets and capital markets, especially China's real estate markets and stock markets. So far, there is no hard data on how much speculative capital has flown into what markets. Some argue that at least one-third of China's current account surplus in 2006 is disguised capital inflows though over-invoicing exports and underinvoicing imports. I prefer to think that most speculative capital might have entered China via the capital account and ended up with China's stock markets and real estate markets.

To channel speculative capital on a large scale across borders into China is not difficult. For example, there are numerous Taiwanese companies with a certain amount of registered capital. However, capital is allowed to be injected gradually over the years. To utilise these loopholes, hedge funds can put money into those enterprises' accounts as injected capital, legally with a price. Then this money will leave the account of these corporations and enter into their subsidiaries' accounts. Now it is entirely legal for these subsidiaries to put the money into their accounts held by securities companies on behalf of them to buy shares. According to a report, one person once single handedly channelled US $\$ 700$ million into stock markets in the short timespan of one month. ${ }^{8}$

I have strong reservations about China's policy of yanjin kuanchu. Stricter control over capital inflows is correct. However, loosening control over capital outflows will not be very helpful for relieving the pressure on the RMB exchange rate. On the contrary, in my view, loosening control over capital outflows will encourage rather than discourage capital inflows, especially speculative capital inflows. If it is so easy to run away, why not come and have a go first? Temptation for buying Chinese assets is too great to resist. First, China's real estate and financial assets are cheap in terms of foreign currencies. Even without RMB appreciation, they are worthwhile to buy. ${ }^{9}$ Second, the RMB is expected to appreciate by at least 25 per cent in years to come, by international investors. Third, the potential for the prices of Chinese assets to rise is great. For example, until late 2005, China's share price was less than 1,300 points and now it has broken the threshold of 3,000 points. Though the share price is no longer cheap, the potential for China's other financial and real assets to rise is still great. Fourth, Chinese interest rates are higher than corresponding international interest rates, especially higher than those of Japanese interest rates. (Why is there not more carry trade?) Fifth, the Chinese government's repeated injections of capital into troubled commercial banks makes foreign as well as domestic investors believe that the Chinese assets are not risky at all because of the implicit guarantees by the government. Sixth, China's huge foreign exchange reserves are the ultimate collaterals for all foreign investment. What can be more reassuring?

Under these circumstances, probably only two kinds of capital will be eager to utilise opportunities provided by the 'loosening control over capital outflows' to flow out of China: the unwinding speculative capital and money that needs to be bleached. Legitimate outbound investment and remittance of investment incomes already have channels in place to move out of the borders without undue difficulties. However, even this legitimate outbound investment should be carefully monitored and supervised. China should not repeat Japan's painful experience immediately after the Plaza accord, when the Japanese bought foreign assets gleefully and then lost almost all of them a few years later. Without careful monitoring and supervising, the results of the disorderly outflows of Chinese capital will fare much worse than the Japanese who went on a buying spree two decades ago. Prasad pointed out that 'many of the emerging markets with closed capital accounts have underlying fragilities like a huge fiscal deficit, a banking sector with significant non-performing loans, or an opaque corporate non-financial sector, which make full capital account convertibility risky'. On top of the usual problems with developing countries' capital outflows, China is a country without clearly defined property rights. $A$ great portion of public assets have been stolen quietly by the so-called stealth privatisation. To channel the stolen money to Virgin Island and/or Cayman Island is the best ending for the thievery. For some state-owned enterprises, managers can be very careless about whether other people's money will go down the drain, because of a lack appropriate incentive mechanisms and low morality. In short, before further institutional reform is accomplished, and right corporate governance is put in place, to encourage capital outflows for the purpose of relieving the pressure on $\mathrm{RMB}$ appreciation is indeed 'putting the cart before the horse'.

Some in China argue that capital control is ineffective anyway and hence why bother? I agree that China's capital control is extremely leaky. However, it is not right to underestimate the effectiveness of capital 
control all together, when the authorities are determined to make it effective. At least, the government can do something to increase the transaction cost to the illegitimate cross-border capital flows. Though the Thai government was criticised universally for its bungled recent efforts in managing capital flows, the episode shows that how to manage capital flows again has become the priority of macroeconomic policy. Thai monetary authorities' recent actions aimed at stopping speculative capital inflows are understandable, although mistakes have been made in terms of tactics and technicalities. The Thai experience also shows that after the firewall has been torn down, it is extremely difficult to re-erect it. Efforts in restoring some control over capital movement will cause stronger reactions by foreign investors than if the control has not been dismantled yet. Therefore, China should not be in a hurry to dismantle capital control. Rather it should improve its management of capital flows.

In my view, at this moment, the stability of the Chinese economy hinges on the success of China's management of capital flows. China's household saving deposits amount to 17 trillion yuan (US\$2.3 trillion) and account for 85 per cent of GDP in 2006. We cannot rule out the possibility that Chinese households suddenly decided that they should hold a certain proportion, e.g. 20 per cent of their savings in the form of foreign assets. If diversification happens, the total amount of capital outflows will amount to US $\$ 400$ billion. Furthermore, China's FDI stock must be greater than US\$500 billion and the corresponding investment income outflows can be as high as US\$50 billion to US\$100 billion. Finally, China's balance of foreign borrowing is US\$305 billion, among which, short-term borrowing is US\$169 billion. If capital flows reverse, due to whatever reasons rational or irrational, the total amount of capital outflow in a short span can be as high as half a trillion US dollars. If reversal happens, the consequences will be very grave indeed. Therefore, in my view, if China makes a fatal mistake in the next five years, the mistake will be the premature abandonment of capital controls aimed at reducing RMB appreciation pressure.

\section{Conclusion}

Some ten years after the Asian financial crisis, the Asian economy is in much better shape. The recovery of the Asian economy shows that the Asian miracle is true. Asia has the will and ability to continue its miracle to further narrow its gap with the developed economies. However, it should be recognised that all is not well in Asia. Ten years after the Asian financial crisis, Asian economies are facing similar challenges and threats. All East Asian economies are facing appreciation pressure. All East Asian economies are facing speculative capital inflows. History will not repeat itself in the exact same way. But something wrong, and suspiciously familiar, is apparent. Asian economies should raise vigilance. Otherwise, we will once again fall prey of predators in the form of hedge funds and private equity funds. With experience we have learnt, if we fail this time, besides ourselves, there is no one we can blame.

\section{Notes}

* This article was prepared for the Bangkok Conference, 25-26 February 2007, part of an IDS, Thai Development Research Institute and Seoul University project.

1 See Is China Stable, by Shambaugh, D. and Sharpe, M.E., eds (1999) New York: Armonk.

2 Now AMCs will be transformed into certain nonbank financial institutions.

3 Nafang Zhoumo (2006) Southern Weekend 28 September: C22.

4 See: http://finance.sina.com.cn (accessed 24 April 2006).

5 Nafang Zhoumo (2006) Southern Weekend 28 September: C22.

6 It is worth mentioning that the 270 billion RMB special government bonds are long-term bonds. The

maturity is 30 years. The bonds are marketable in the inter-bank bond market, and hence liquid. The coupon interest rate of the bonds is 7.2 per cent p.a.

7 Later, different figures were provided. So far, there is no commonly accepted official figure of the investment rate. Most Chinese economists think the figure should be between 40 and 45 per cent.

8 Dai, Y. (2007) 'A Special Report: How Foreign Capital Is Manipulating China's Stock Markets', China Business 22 January: A9.

9 Due to the relatively cheap prices as well as RMB appreciation expectations, Hong Kong residents' investment in Mainland's real estates totalled 15 billion yuan; an increase of 11 per cent over 2005 (Lianhe Zao Bao (2007) Singapore, 20 February: 19). 


\section{References}

Kwame Sundaram, Jomo (ed.) (1998) Tigers in Trouble, London: Zed Books

Nanfang Zhoumo (Southern Weekend), 28 September 2006: C22

Radelet, Steven and Sachs, Jeffrey, D. (1998) The East Asian Financial Crisis: Diagnoses, Remedies, Prospects, Brookings Papers on Economic Activity 1, Washington DC: The Brookings Institution Rodrik, Dani (1998) Who Needs Capital Account Convertibility?, Princeton Essays in International Finance 207, Princeton, New Jersey: Princeton University: 1-10

Shambaugh, D. and Sharpe, M.E. (eds) Is China Stable, New York: Armonk
Wang, J. (2006) 'China's Macroeconomic Situation', East Asia Institute lecture note, unpublished

Williamson, John (1995) The Management of Capital Inflows, Working Paper, January-June,

Pensamiento Iberoamericano

Woo, Wing Thye; Sachs, Jeffrey, D. and Schwab, K. (eds) (2000) The Asian Financial Crisis, Cambridge MA: The MIT Press

Yu, Yongding (2005) 'China's Rise Twin Surplus and the Change of China's Development Strategy', paper prepared for Namura Tokyo Club Conference, Kyoto, 21 November 